\title{
TRANSFORMASI NILAI PENDIDIKAN AGAMA HINDU DALAM MENGANTISIPASI \\ KASUS HAMIL PRANIKAH DI DESA ABIANSEMAL DAUH YEH CANI, KECAMATAN ABIANSEMAL, KABUPATEN BADUNG \\ Oleh
}

\author{
I Wayan Butuantara \\ Dosen Fakultas Pendidikan Agama dan Seni UNHI
}

\begin{abstract}
ABSTRAK
Gaya hidup remaja saat ini lebih banyak dipengaruhi oleh gaya hidup modern. Yang tercermin dari prilaku dan aktivitas remaja saat ini seperti tata cara berpakaian, dan bahkan seks di luar nikah. Seks Pra nikah sebagai salah satu akibat dari pergaulan remaja saat ini menjadi sebuah momok yang mengerikan bagi orang tua sebab Seks pranikah tentu saja berkorelasi dengan Kehamilan yang tidak di inginkan dan tindakan criminal seperti aborsi. Remaja sekarang lebih banyak terhanyut pada kehidupan modern. Ingin bebas dalam artian tidak terbatas, seperti perilaku seksual yang cenderung bebas dilakukan tanpa ada ikatan perkawinan yang sah. Faktor terjadinya hamil pranikah di desa Abiansemal Dauh Yeh Cani, Kecamatan Abiansemal, Kabupaten Badung yaitu (1) Faktor Internal (dalam diri), yaitu : psikologis, kurangnya pemahaman pendidikan agama Hindu; (2) Faktor Eksternal (luar diri), yaitu : kurangnya kontrol dan perhatian dari orang tua, lingkungan sosial (masyarakat) dan kemajuan IPTEK, pengaruh buruk lingkungan

Berdasarkan permasalahan dalam penelitian ini maka peneliti mengkaji penelitian ini berdasarkan? (1) Mengapakah terjadi hamil pranikah di desa Abiansemal Dauh Yeh Cani, Kecamatan Abiansemal, Kabupaten Badung? (2) Implementasi nilai pendidikan agama Hindu apa saja yang dilakukan dalam mengantisipasi kasus hamil pranikah di desa Abiansemal, Kecamatan Abiansemal, Kabupaten Badung?. penelitian ini bertujuan untuk memberikan pemahaman tentang pendidikan agama Hindu bagi remaja dalam mengantisipasi kasus hamil pranikah pada umumnya sehingga dengan demikian pada gilirannya akan tercapai pemahaman yang lebih jelas dikalangan masyarakat khususnya para remaja mengenai hal itu, sedangkan manfaat lain dari penelitian ini adalah dapat menambah khasanah keilmuan khususnya agama Hindu terhadap masalah-masalah yang erat hubungannya dengan implementasi nilai pendidikan agama Hindu bagi remaja dalam mengantisipasi kasus hamil pranikah agar terhindar dari hal-hal yang tidak diinginkan.
\end{abstract}

Kata Kunci: Transformasi, Nilai, Pendidikan Agama Hindu

\section{ABSTRACT}

Today's lifestyle is more influenced by modern lifestyles. Which is reflected in the behavior and activities of today's teenagers such as the procedure for dressing, and even extramarital sex. Pre-marital sex as a result of adolescent association is now a terrible scourge for parents because premarital sex certainly correlates with unwanted pregnancies and criminal acts such as abortion. Teenagers are now more absorbed in modern life. Want to be free in an unlimited sense, such as sexual behavior that tends to be free is done without a legitimate marriage bond. Factors in the occurrence of premarital pregnancy in the village of Abiansemal Dauh Yeh Cani, District of Abiansemal, Badung Regency are (1) Internal (internal) factors, namely: 
psychological, lack of understanding of Hindu religious education; (2) External factors (outside self), namely: lack of control and attention from parents, social environment (community) and the progress of science and technology, bad influence of the environment

Based on the problems in this study, the researcher reviews this research based on? (1) Why is there premarital pregnancy in the village of Abiansemal Dauh Yeh Cani, Abiansemal District, Badung Regency? (2) What is the implementation of the value of Hindu religious education in anticipating premarital pregnancy cases in Abiansemal village, Abiansemal District, Badung Regency ?. this study aims to provide understanding of Hinduism education for adolescents in anticipating premarital pregnancy cases in general so that in turn this will result in a clearer understanding among the community, especially teenagers about it, while other benefits of this research are to be able to add scientific knowledge especially Hinduism on problems that are closely related to the implementation of the value of Hindu religious education for adolescents in anticipating premarital pregnancy cases to avoid undesirable things.

Keywords: Transformation, Value, Hinduism Education

\section{PENDAHULUAN}

Remaja adalah masa muda dimana ego masih tinggi dan mencari jati diri, hal ini yang membuat remaja memiliki rasa ingin tahu yang tinggi. Masa ini adalah masa yang intensif dalam memberikan pendidikan budi pekerti dan mengajarkan serta pendekatan diri kepada Tuhan. Masa remaja disebut juga sebagai masa penghubung atau peralihan antara masa kanak-kanak dengan masa dewasa. Pada periode ini terjadi perubahanperubahan besar dan esensial mengenai kematangan fungsi-fungsi rohaniah dan jasmaniah, terutama fungsi seksual. Remaja pada periode ini yang menonjol adalah kesadaran yang mendalam mengenai diri sendiri, anak muda yang mulai meyakini kemauan, potensi dan cita-cita sendiri. Dengan kesadaran tersebut ia berusaha menemukan jalan hidupnya dan mulai mencari nilai-nilai tertentu seperti kebijaksanaan, keluhuran dan sebagainya.

Pergaulan dalam masyarakat dapat mempengaruhi sikap mental dan perilaku seseorang. Dalam kehidupan, manusia dibimbing oleh nilai-nilai yang merupakan pandangan mengenai apa yang baik dan apa yang buruk. Nilai yang baik harus diikuti, dianut sedangkan nilai yang buruk harus dihindari. Sesuai aspek rohaniah dan jasmaniah yang ada pada manusia, maka manusia dibimbing oleh pasangan nilai materi dan non materi, maka sebaiknya kedua nilai ini merupakan pasangan yang diserasikan. Akan tetapi kenyataannya dewasa ini menunjukkan bahwa nilai materi mendapat tekanan lebih besar daripada nilai non materi atau spiritual. Hal ini terbukti kenyataan 1 
bahwa sebagai tolak ukur peranan seseorang dalam masyarakat adalah kebendaan dan kedudukan.

Remaja sekarang lebih banyak dipengaruhi oleh gaya hidup modern. Gaya hidup modern buktinya bisa dilihat dari tata cara berpakaian, seperti pakaian agak ketat dengan memperlihatkan perut, pusar bahkan karet celana dalam kelihatan, rambut disemir dengan berbagai macam warna, dan seks di luar nikah semakin banyak dilakukan. Kebanyakan di antara mereka kehilangan pegangan hidup, moral, nilai ataupun yang disebut dengan norma yang merupakan warisan leluhur terdahulu seperti kekawin, lontar-lontar, kidung yang di dalamnya banyak memuat nilai adi luhung yang berfungsi mengarahkan hidup yang berasal dari kitab-kitab suci. Remaja sekarang lebih banyak terhanyut pada kehidupan modern. Ingin bebas dalam artian tidak terbatas, seperti perilaku seksual yang cenderung bebas dilakukan tanpa ada ikatan perkawinan yang sah.

Melihat berbagai fenomena mengenai hamil pranikah yang sudah banyak terjadi di kalangan remaja Bali, maka penulis tertarik untuk meneliti tentang implementasi nilai pendidikan agama Hindu bagi remaja dalam mengantisipasi kasus hamil pranikah di desa
Abiansemal Dauh Yeh Cani, Kecamatan Abiansemal, Kabupaten Badung. Berdasarkan hasil di lapangan dari jumlah penduduk 5,856 dengan 6 banjar, menurut I Wayan Sutama selaku perbekel (wawancara, 1 Maret 2015) Mengingat perkembangan zaman (globalisasi) umur perkawinan dari tahun ke tahun semakin muda. Banyak anak-anak remaja yang tidak mengindahkan peringatan orang tua, semua orang tua mungkin sudah memberi perhatian yang lebih terhadap perkembangan masa remajanya. Anak remaja yang tidak mau tau sebab-akibat dari pergaulan mereka, dari pergaulan yang bebas maka banyak anak-anak remaja yang mengalami hamil pranikah bahkan ada yang hamil masih duduk di bangku sekolah. Perkawinan pranikah di zaman sekarang ini sangat meresahkan orang tua. Sebagai orang tua di zaman saat ini harus lebih ektra ketat mengawasi anak-anaknya apalagi sekarang fasilitas sangat menunjang pergaulan bebas anak remaja. Lain halnya dizaman dahulu, anak-anaknya sangatlah mengerti akan pergaulan, nasehat orang tua dituruti disamping fasilitas seperti sepeda motor dan telephone tidak ada (Suadnyana, 2018).

Dari tahun ke tahun anak-anak remaja yang hamil pranikah semakin meningkat. Belakangan tiga tahun terakhir dari tahun 
2011 sampai tahun 2014 anak remaja yang hamil pranikah mencapai 92 orang / kasus. Keadaan ini sangat memprihatinkan dan perlu adanya kajian penelitian yang mendalam mengapa perilaku hamil pranikah itu terjadi di desa Abiansemal Dauh Yeh Cani dilihat dari perspektif Pendidikan Agama Hindu.

\section{Faktor Terjadinya Hamil Pranikah Di} Desa Abiansemal Dauh Yeh Cani, Kecamatan Abiansemal, Kabupaten Badung.

Remaja yang mengalami hamil
pranikah atau seks pranikah di desa
Abiansemal Dauh Yeh Cani disebabkan oleh
dua faktor, yaitu Faktor Internal dan Faktor
Eksternal:

\section{a. Faktor Internal.}

Faktor Internal adalah faktor-faktor yang berasal dari dalam diri seseorang, yang meliputi:

\section{(1) Psikologis.}

Peperangan bathin dalam diri seseorang nampaknya merupakan masalah tersendiri yang tidak ringan, sering kali kita mendengar seseorang yang bunuh diri atau frustasi dan tidak berharga lagi. Ini adalah salah satu dari sekian banyak kegagalan manusia dalam mengatasi berbagai masalah kepribadian. Banyak orang yang sudah cukup usia namun tidak mampu melawan tantangan nafsu-nafsunya sendiri oleh sebab itu maka banyak penyelewengan dan kasus perkosaan, perzinahan dan banyak tindak susila lain yang dilakukan oleh seseorang.

Pada remaja faktor rohaniah anak yang dipandang lebih esensial meliputi : minat dan motivasi. Berdasarkan hasil penelitian, minat dan Motivasi menjadi kondisi yang menjadi faktor utama sehingga terjadinya seks pra nikah ini, minat adalah kecenderungan dan kegairahan yang tinggi atau keinginan yang besar terhadap sesuatu. Disisi lain Minat juga merupakan penerimaan akan suatu hubungan antara diri sendiri dengan sesuatu diluar diri. Minat yang dimiliki remaja dapat diekspresikan melalui suatu pernyataan yang menunjukkan hubungan bathin berupa perasaan suka terhadap lawan jenis. Akibat adanya gendering dampak negative dari globalisasi dan internetisasi yang tentu memberi peluang bagi remaja untuk mengakses segala cara untuk menunjukkan minatnya itu, sebagaimana dalam wawancara dengan I Wayan Sumendra menyatakan bahwa :

Remaja saat ini, lebih banyak mengakses media sosial dan mengakses video-video yang berbau porno dengan Hp yang ia miliki. Akibat dari menonton video tersebut gairah seksualnya pada akhirnya meningkat sehingga memculkan minat untuk melakukan adegan seks dengan pacarnya. 
Faktor Motivasi mempengaruhi keaktifan keaktifan remaja di dalam merealisasikan minat yang dimilikinya itu. Motivasi juga diartikan sebagai proses yang memberi semangat, arah, dan kegigihan perilaku. Artinya, perilaku yang termotivasi adalah perilaku yang mengarahkan perilaku untuk mencapai tujuan.

\section{(2) Kurangnya Pemahaman Pendidikan}

\section{Agama Hindu.}

Kurangnya pendidikan pada anak remaja yang diberikan oleh orang tua merupakan salah satu faktor penyebab terjadinya perilaku menyimpang pada anak remaja di desa Abiansemal Dauh Yeh Cani karena orang tua merupakan lingkungan yang paling dekat dengan anak. Hal tersebut sesuai dengan pernyataan teori konflik bahwa perilaku menyimpang anak terjadi karena adanya pertentangan orang tua dengan anak. Sering kali anak didominasi oleh orang tua sehingga menimbulkan konflik sosial antar dua generasi. Orang tua mengupayakan pendidikan anak melalui cara dan metode yang benar menurut orang tua tanpa memperdulikan kondisi anak, yang menyebabkan perilaku anak jauh menyimpang dari harapan orang tua terhadap anak. Hal tersebut terjadi karena anak merasa ada tekanan dari orang tua melalui pendidikan yang dipaksakan oleh orang tua.

Kurangnya pendidikan dimaksudkan berupa kesalahan pendidikan yang diberikan orang tua kepada anak dan kesalahpahaman orang tua terhadap pendidikan agama Hindu tersebut. Kurangnya pendidikan agama Hindu oleh orang tua dapat berupa ketidakharmonisan hubungan dalam keluarga. Keluarga yang tidak harmonis sering kali mengabaikan pendidikan moral (Agama) anak, apabila terjadi penyimpangan perilaku oleh anak sering kali orang tua saling menyalahkan tanpa ada usaha atau komunikasi untuk menyelesaikan permasalahan anak tersebut. Orang tua yang tidak memberikan teladan perilaku yang baik kepada anak, karena orang tua beranggapan pendidikan diberikan dan merupakan tanggung jawab gurunya di sekolah, kewajiban orang tua hanya menyediakan kebutuhan materi. Kurangnya komunikasi terhadap anak sehingga anak merasa diacuhkan oleh orang tua sehingga tidak ada pembimbing perilaku anak ke arah yang baik. Orang tua yang terlalu sibuk bekerja sehingga jarang mengetahui keadaan moral, sikap dan perilaku anak serta mempercayakan pendidikan anak kepada pembantu merupakan bibit-bibit munculnya perilaku menyimpang anak. Kurangnya 
pendidikan oleh orang tua dan kesalahpahaman orang tua terhadap ajaran agama Hindu, bahwa agama Hindu hanya untuk orang yang berusia lanjut sehingga orang tua beranggapan anak nantinya akan belajar sendiri setelah dewasa tentang ajaran agama Hindu, misalnya mesanthi, mekidung, membuat banten dan sebagainya. Dalam wawancara dengan I Wayan Budana menyatakan sebagai berikut :

"Kesalahan pendidikan agama Hindu oleh orang tua kepada anaknya ketika masa kanak-kanak sampai remaja menjadikan anak seorang pribadi yang sulit diatur, melanggar aturan yang ada dan cenderung berprilaku menyimpang serta tidak percaya ajaran agama (wawancara tanggal 5 Maret 2015)".

Senada dengan pendapat tersebut I Wayan Bakia selaku tokoh masyarakat desa Abiansemal Dauh Yeh Cani menuturkan sebagai berikut :

"Orang tua yang acuh terhadap pendidikan anaknya, apapun yang dilakukan anaknya dibiarkan tanpa ada nasehat. Sikap yang demikian menjadikan anak yang arogan. Kerap melanggar aturan yang berlaku sehingga menunjukkan perilaku yang menyimpang. Anak dibiarkan berbuat apa saja, bergaul dengan siapa saja dan dibiarkan berkembang sesuai dengan kemauan anak sendiri menjadikan anak sulit diatur. Anggapan orang tua yang hanya memberikan kebutuhan materi saja dan mengabaikan kebutuhan moral menjadikan anak berperilaku menyimpang. Ditekankan olehnya bahwa tanpa bekal pendidikan moral oleh orang tua, seorang anak akan menunjukkan perilaku-perilaku menyimpang yang menjurus ke tindakan kriminal"

Kedua pendapat tersebut menjelaskan bahwa orang tua berkewajiban memberi pendidikan anak-anaknya dan bertanggung jawab terhadap pendidikan anak-anaknya. Orang tua yang salah mendidik atau salah menanamkan nilai-nilai agama merupakan sumber terjadinya perilaku-perilaku menyimpang pada anak. Munculnya bibitbibit penyimpangan perilaku tersebut dikarenakan tidak ada pendidikan di keluarga. Pendidikan yang salah tersebut terus berakar pada diri anak dan membentuk moral dan karakter yang buruk. Dari perilaku-perilaku yang menyimpang tersebut, mulai terjadi pelanggaran-pelanggaran serta mengarah ke tindak kriminal yang perlu penyelesaian secara hukum.

\section{(2) Faktor Eksternal.}

Faktor Eksternal merupakan faktor yang berasal dari luar diri seseorang, yang meliputi

(1) Kurangnya Kontrol dan Perhatian dari

\section{Orang Tua.}

Pendidikan dalam keluarga memiliki nilai prima dalam pembentukan kepribadian 
anak. Sejak kecil anak sudah mendapat pendidikan dari kedua orang tuanya terutama ibu melalui keteladanan dan kebiasaan hidup sehari-hari dalam keluarga. Baik tidaknya keteladanan yang diberikan dan bagaimana kebiasaan hidup orang tua sehari-hari dalam keluarga akan mempengaruhi perkembangan jiwa anak. Keteladanan dan kebiasaan yang orang tua tampilkan dalam bersikap dan berperilaku sangat mempengaruhi perhatian dan pengamatan anak.

Meniru kebiasaan hidup orang tua bahkan melihat sikap orang tua adalah suatu hal yang sering dilakukan anak karena memang pada masa perkembangannya anak selalu ingin meniru apa-apa yang orang tua lakukan. Komunikasi dialogis yang terjadi antara orang tua dan anak-anaknya, terutama yang berhubungan dengan upaya membantu anak untuk memecahkan permasalahan berkenaan dengan nilai-nilai pendidikan agama Hindu. Dengan demikian rang tua telah mampu melakukan kontrol terhadap perilakuperilaku anak-anaknya agar mereka tetap memiliki dan meningkatkan nilai-nilai pendidikan agama Hindu sebagai dasar berperilaku yang baik. Melalui kontrol tersebut, berarti orang tua telah melakukan pengawasan dan bimbingan kepada anaknya untuk berperilaku sesuai dengan nilai pendidikan agama Hindu. Dalam mengontrol perilaku anak, orang tua dapat memberikan hukuman, jika hal tersebut dirasakan sangat perlu untuk menyadarkan anak terhadap perilaku-perilakunya yang menyimpang sehingga dapat diluruskan kembali.

\section{(2) Lingkungan Sosial (Masyarakat) dan Kemajuan IPTEK}

Zaman sekarang anak-anak remaja sangat rentan terhadap bahaya pornografi yang berdampak buruk bagi perkembangan mental, pola pikir dan emosi mereka karena masih bergelut dengan pergolakan jiwa remajanya. Mengetahui sedikit informasi saja, mereka penasaran untuk belajar mengakses internet. Tetapi, resikonya tidak bisa dianggap enteng. Sebab, tanpa pengawasan dan pendampingan orang tua / keluarga, anak-anak akan mudah terjerat ke dalam ketagihan buruk dari hal-hal baru yang sama sekali belum diketahui. Anakanak memang belum dewasa. Maka, mereka belum mampu memilih dan memilah mana informasi yang baik dan buruk.

Dampak buruk pornografi pada perilaku anak-anak awalnya distimulasi oleh pengalaman libido pribadi dalam momen kesendirian. Sebab itu, saat mengakses internet harus dalam pengawasan dan pendampingan orang tua sebagai bentuk tanggung jawab dalam melindungi anak. 
Tanpa pendampingan dari orang tua mungkin anak-anak meniru apa yang dilihat dan diinginkannya. Pornografi bisa lebih cepat di akses oleh masyarakat, termasuk oleh anakanak remaja di tengah maraknya warnet di seantro tanah air. Sayangnya, sejak lama pemerintah kita kurang peduli untuk menyensor konten internet. Lebih-lebih pornografi sangat mudah menular dari HP ke HP. Jangankan anak di bawah umur 18 Tahun, bahkan sifat aditif mental dari melihat video porno merusak otak dan sistem hormonal orang dewasa. Menurut para ahli kecanduan video porno memiliki daya perusak mental yang nyaris sama dengan mengonsumsi narkoba dan miras. Walhasil, individu bersangkutan menjadi mati rasa malu sehinggga mudah kebablasan dalam berbuat sesuatu yang sesuai ambisi dan selera perilakunya. Video porno, internet, penyebaran pornografi dan pornoaksi sangat berpotensi menimbulkan wabah virus mental dan penyakit sosial.

Hal itu memberikan stimulasi besar bagi pecandunya untuk hubungan intim di luar nikah. Lebih bahaya lagi, emosi / pikiran si penzina menjadi lepas kendali sehingga mudah terjerumus ke dalam tindak kriminal seperti pembunuhan dan pemerkosaan.
Terlepas semua yang terjadi di atas maka terjadi kejadian hamil di luar nikah.

\section{Transformsi Nilai Pendidikan Agama} Hindu Mengantisipasi Kasus Hamil Pranikah Di Desa Abiansemal Dauh Yeh Cani, Kecamatan Abiansemal, Kabupaten Badung.

\section{Nilai Religius.}

Mampu berterima kasih dan bersyukur, menghormati dan mencintai Tuhan yang diwujudkan dalam doa. Hal ini dalam agama Hindu dikaitkan dengan ajaran Panca Sradha yaitu sebagai dasar keyakinan umat Hindu selalu menjiwai setiap perilakunya sehari-hari sebagai cerminan manusia beragama. Perilaku yang dijiwai oleh suatu keyakinan yang sungguh-sungguh biasanya memancarkan vibrasi menyejukkan di lingkungannya, oleh karena itu keyakinan merupakan sesuatu yang sangat diperlukan dalam kehidupan manusia. Hidup tanpa keyakinan ibarat berjalan dengan memejamkan mata yang bermuara pada kehidupan yang tidak menentu dan tanpa tujuan yang pasti. Keyakinan dalam hidup mutlak diperlukan karena keyakinan adalah suatu kemampuan yang terdapat pada diri manusia yang diperoleh melalui kepercayaan.

Memahami keberadaan Atman dalam diri diharapkan remaja Hindu bisa memilah mana perbuatan baik dan mana perbuatan 
buruk, karena hal itu yang akan menentukan Atman masuk Surga atau Neraka, mengalami kebahagiaan atau penderitaan tergantung dari perbuatan manusia yang dilakukan semasih hidup. Pada sisi lain setiap masa kehidupan tertentu, makhluk hidup khususnya manusia tidak akan putus-putusnya melakukan karma. Oleh karena itu iapun tidak putus-putusnya menikmati hasil perbuatannya dan manusia selalu akan berada di dalam lingkaran karma. Kelahiran seseorang tergantung dari karma yang dilakukan semasih hidup. Jika baik karmanya maka kelahiran menjadi manusia akan diperoleh, demikian sebaliknya jika perbuatan buruk yang membelenggu sang Atman niscaya kelahiran menjadi binatang atau makhluk lain yang akan diperoleh. Dengan paham akan arti dari hukum karma phala remaja Hindu akan lebih berhati-hati dalam melangkah sehingga terhindar dari pengaruh negatif termasuk hamil pranikah.

Di dalam keluarga Hindu penerapan Punarbhawa dilakukan dengan memberikan pemahaman kepada anak bahwa kelahiran yang berulang-ulang dapat menghambat atma yang ada pada diri untuk bersatu dengan Brahman. Orang tua memberikan contoh nyata dimana pada saat bayi itu lahir maka diadakanlah upacara Ngaluang. Upacara ini dimaksudkan untuk mengetahui siapa leluhur

yang menjelma kembali pada tubuh bayi itu. Ini merupakan suatu bukti bahwa punarbhawa itu memang benar-benar ada dan terjadi pada kehidupan setiap makhluk.

\section{Nilai Etika (Susila).}

Mampu bertoleransi dalam setiap kegiatan di lingkungannya, menghindari tindakan mau menang sendiri serta memperbaiki diri melalui saran dan kritik dari orang lain. Hal ini dalam Agama Hindu dikaitkan dengan ajaran Tri Kaya Parisudha merupakan hal yang tak asing lagi di kalangan umat Hindu sebab ajaran tersebut telah mendarah daging di lingkungan masyarakat utamanya di desa Abiansemal Dauh Yeh Cani. Hal ini didapatkan oleh anak semenjak mengenal lingkungan dimana dirinya terlahirkan, dengan demikian ajaran tersebut hendaknya ditanamkan sejak dini pada anak, lebih-lebih di jaman globalisasi sekarang ini. Salah dalam menempatkkan kata-kata maupun berbuat maka akan fatal akibatnya. Disini penting peran keluarga dan orang tua untuk mengajarkan pada anak-anaknya bagaimana berpikir, berkata dan berbuat baik antar sesama dan makhluk lain di dunia ini.

\section{Nilai Bhakti.}


Menurut ajaran agama Hindu, bhakti merupakan sikap hormat, ketulusan hati seseorang terhadap Ida Sang Hyang Widhi Wasa maupun terhadap orang tuanya. Bhakti adalah pondasi dasar untuk dapat menjalani keseharian dengan lebih baik dan melalui ajaran ini manusia mencapai kebahagiaan dan kedamaian dalam kehidupannya. Manusia yang mampu menjalani kehidupan di dunia dengan berlandaskan ajaran agama Hindu, pasti memperoleh keyakinan dan kepercayaan. Oleh karena dengan nilai tersebut, mampu meningkatkan bhakti seseorang terhadap Tuhan Yang Maha Esa.

\section{PENUTUP}

Berdasarkan pembahasan-pembahasan pada sub pembahasan di awal pada tulisan ini, maka penulis temukan beberapa kesimpulan yang merupakan jawaban dari permasalahan yang di bahas yakni sebagai berikut:

a) Faktor terjadinya Hamil Pranikah di desa Abiansemal Dauh Yeh Cani yaitu :

Faktor Internal adalah faktor-faktor yang berasal dari dalam diri seseorang, yang meliputi : Psikologis, Kurangnya pemahaman pendidikan agama Hindu. (2) Faktor Eksternal merupakan faktor yang berasal dari luar diri seseorang, yang meliputi : kurannya kontrol dan perhatian dari orang tua, lingkungan sosial (masyarakat) dan kemajuan IPTEK, pengaruh buruk lingkungan.

b) Nilai pendidikan agama Hindu yang dapat yang dapat di transformasikan dalam mengantisipasi kasus Hamil Pranikah di desa Abiansemal Dauh Yeh Cani, Kecamatan Abiansemal, Kabupaten Badung yaitu Nilai Religius diimplementasikan dalam konsep Panca Sradha yaitu percaya dengan adanya Tuhan, percaya dengan adanya Atman, percaya dengan adanya Karma Phala, percaya dengan adanya Punarbhawa, dan percaya dengan adanya Moksa. Nilai Etika (Susila) diimplementasikan dalam konsep Tri Kaya Parisudha yaitu Manacika Parisudha, Kayika Parisudha dan Wacika Parisudha. Nilai Bhakti.

\section{DAFTAR PUSTAKA}

Pudja. M.A.G. 1973. Manawa Dharmacastra. Jakarta : Lembaga Penterjemah Kitab Suci Veda.

Pudja. M.A.G. 1984. Sradha. Jakarta : Mayasari.

Punyatmaja, Drs. Ida Bagus Oka. 1994. Cilakrama. Penerbit PT Upadasastra (Cetakan II).

Sarwono, 1980. Psykologi Remaja. Jakarta: Raja GrafindoPersada. 
Suadnyana, Ida Bagus Putu Eka. "KAJIAN NILAI PENDIDIKAN AGAMA HINDU DALAM KONSEP MANYAMA BRAYA." Jurnal PASUPATI 5.1 (2018): 48-60.

Sudirga, Ida Bagus, dkk. 2007. Widya

Dharma Agama Hindu. Jakarta : Ganesa Exact.

Sugiyono, 2007. Metoda Penelitian Kualitatif, Kwantitatif dan R\&D. Bandung: Alfabeta.

Suhardana, K.M. 2007. Tri Kaya Parisudha. Denpasar : Paramita.
Sujaelanto, I Nyoman Arthayasa dan Yeti Suneli, Ketut. 2004 petunjuk teknis "Perkawinan Hindu" Surabaya Paramita. Sukartha, I Ketut, dkk. 2004. Widya Dharma Agama. Bandung: Ganesa.

Sukayani, Ni Kadek. 2013. Pengimplementasian Pendidikan Budi Pekerti di Lingkungan Keluarga Hindu di Desa Blahkiuh (Tesis). Denpasar : Program Pasca Sarjana IHDN. 